\title{
People Acceptance of Rainwater Harvesting In Fisheries Settlement Coastal Area, North Jakarta
}

\author{
A Hargianintya ${ }^{1}$, H S Hasibuan ${ }^{2}$, S S Moersidik ${ }^{3}$ \\ \{nirahargi@gmail.com¹, hayati.hasibuan@ui.ac.id², ssarwanto@eng.ui.ac.id ${ }^{3}$ \} \\ School of Environmental Science, Universitas Indonesia, Indonesia ${ }^{1,2}$ \\ Department of Environmental Engineering, Faculty of Engineering, Universitas Indonesia, Indonesia ${ }^{3}$
}

\begin{abstract}
Muara Angke Fisheries Settlement Area, North Jakarta is a region that potential to experience water scarcity caused by limited water piped network and accompanied by poor groundwater quality due to seawater intrusion. In this situation, rainwater can be an alternative water source to meet household water needs. However, the implementation of Rainwater Harvesting (RWH) in hamlets 22, Muara Angke has not been a priority. Hence, this study aims to assess the acceptance of residents on RWH, their willingness to participate in implementing RWH, and the challenges of installing and maintaining RWH. The study uses the Multi-Dimensional Scaling (MDS) method with social, economic, and environmental aspects. The social aspect consists of 3 indicators: social capital, education, and government support. The economic aspect consists of 3 indicators: income, maintenance cost, and saving. The environmental aspect consists of 3 indicators: the quality, the quantity, and the continuity of rainwater. Data collection in this study involved 93 questionnaires which distributed after socialization of the RWH program and its benefit to the residents. This study analyzes the local people acceptance after socialization the RWH program and benefit to the residents. Results showed that education, social capital, government support, income, maintenance costs, saving, and 3 aspects of rainwater were statistically significant in explaining local resident acceptance of RWH in the study area. The people acceptance of RWH after socialization was change compared to before the socialization.
\end{abstract}

Keywords: Rainwater Harvesting, people acceptance, Coastal Area, Community Access

\section{Introduction}

The coastal area is one of the areas in Indonesia that has a high potential to experience water scarcity. Limitation of water supply, salinity, poor groundwater quality, drought, and groundwater depletion are major difficulties for people to get safe water source. Areas near coastlines with large populations can experience saltwater intrusion due to over groundwater exploitation [1]. Also, tidal waves can flood wells, ponds, and pollute natural sources of freshwater [2]. As a result, this condition will lead to a series of consequences, including the 
emergence of waterborne diseases, loss of livelihood security, and large-scale migration within and across borders [3].

Rainwater Harvesting (RWH) is considered to be a solution to overcome water scarcity in coastal areas. Akter and Ahmed [4] studied the potential of RWH in the urban community of Agrabad Chittagong, Bangladesh. Their study revealed that the RWH allows rainwater to increase clean water by 20 liters/person/day throughout the year. A similar study by Campisano et al. [5] shows that the application of RWH has high annual water savings of $30 \%-50 \%$. If people use the Rainwater Harvesting (RWH) widely, it will have several benefits, such as: overcoming drought, reducing soil erosion, reducing the risk of flooding, increasing groundwater supply, and economical water supply alternatives [6].

Despite abundant benefits to collect rainfall, utilization of rainwater itself is still not optimal even though Indonesia has high rainfall instead [7]. According to Oweis in Shalamzari [8], the main reasons people do not want to use RWH are the role of local government, cost, and system incompatibility with user needs. To achieve the sustainability of RWH, the local people should involve in the planning and development process. For this reason, people perception and acceptance are the critical basis for sustainability of RWH.

This study provides an overview of people acceptance of Rainwater Harvesting (RWH) in fisheries settlement, Muara Angke, North Jakarta. Currently, the local people of Muara Angke have to buy clean water from a local mobile vendor and pay for groundwater usage. People expenditure to purchase clean water is IDR 200.000 - IDR 1.600 .000 every month. According to actual conditions, RWH seems to be a beneficial method for meeting the water needs of the resident in fisheries settlement, Muara Angke. However, the application of RWH in this region has not been a priority. This study aims to assess the acceptance of resident on RWH, their willingness to participate in implementing $\mathrm{RWH}$, and the challenges on installing and maintaining RWH.

\section{Research Methods}

\subsection{Study Area}

The study conducted in a small fisheries settlement area (Rukun Warga (RW) or Hamlet 22) in Muara Angke, North Jakarta. The description of the location and administrative boundaries of Muara Angke is presented in Figure 1. This area can be used to represent the condition in many coastal areas that have the potential to experience water scarcity. 


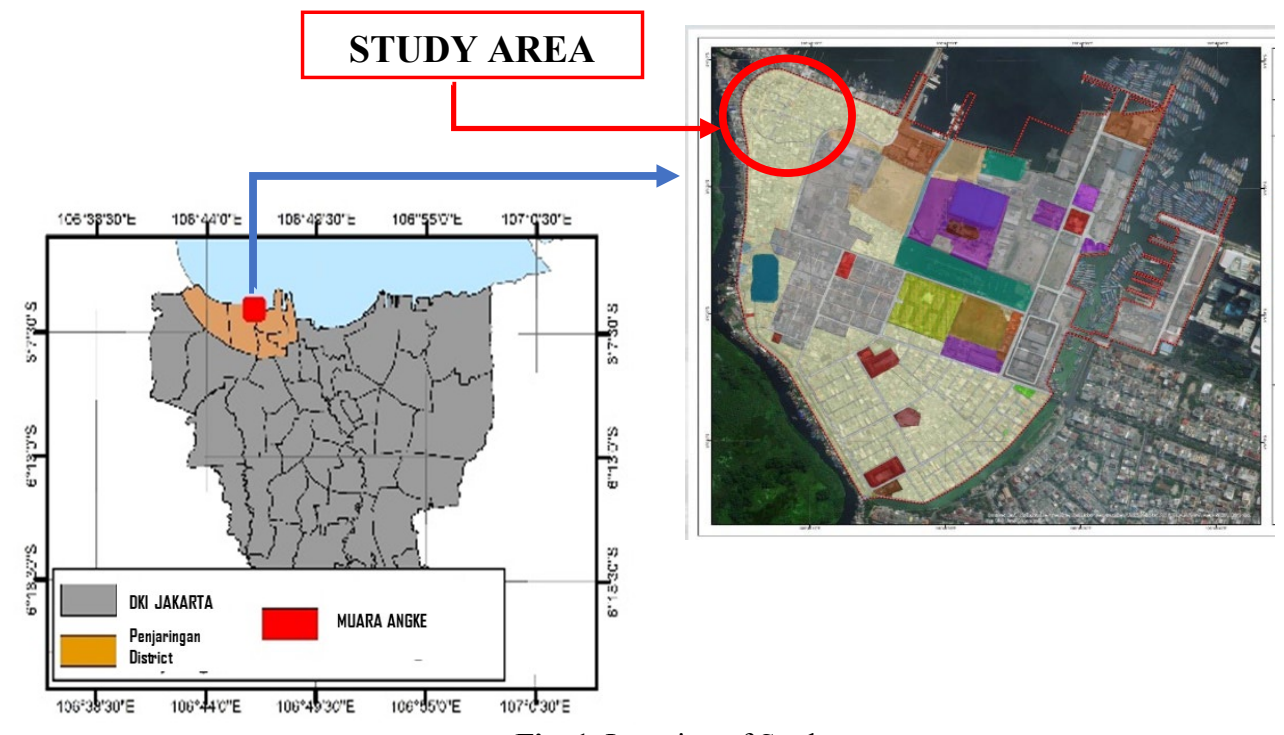

Fig. 1. Location of Study

\subsection{Methodology}

The following methodology was followed to conduct the study:

a. Preparing an initial survey

b. Conducting Forum Group Discussion (FGD) and interviews with community representatives and local government (head of Pluit area, head of RW/hamlets 22 and all neighborhood leader)

c. Conducting socialization and distributing questionnaires that have been developed regarding the initial survey and FGD

d. Processing data and analysis

In this study, respondents are the inhabitants in RW/hamlet 22, Muara Angke, North Jakarta. A total of 93 respondents interviewed. This study used primary data obtained from the questionnaire. The distribution of the questionnaires was carried out after socialization on August 30, 2019. Data processing was used Multidimensional Scaling (MDS) method with SPSS 20. The data consists of 3 aspects: Social, Environment, and Economic aspects. Social aspects consist of 3 indicators: participation, social capital, and government support. Environmental aspects consist of 3 indicators: the quality, the quantity, and the continuity of rainwater. Economic aspects consist of 3 indicators: ability to pay, maintenance cost, and saving. In this study, questionnaires analysis using Likert scoring technique that provides five alternative answers: strongly agree (score:5), agree (score:4), undecided (score:3), disagree (score:2), and strongly disagree (score: 1 ).

\section{Result and Discussion}

\subsection{General Profile of Respondent}

The average age of the respondents was in the age group 36-45 years (38\%), and $32 \%$ of the respondents were in the group 26-35 years (32\%) (Figure 2.a). The range of age population 
shows that the community was productive, potential, and active. Overall there were more females $(82 \%)$ than there were males $(18 \%)$ (Figure 2.b).

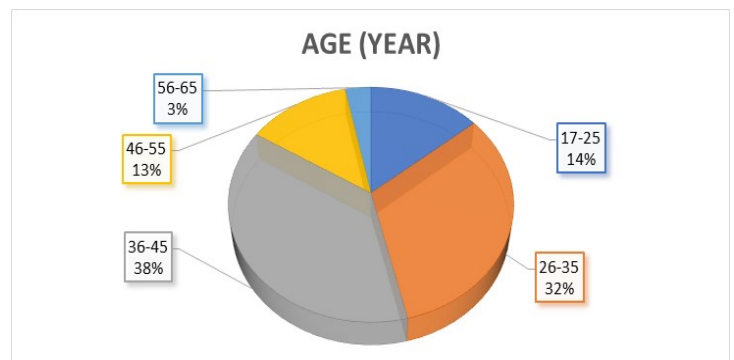

(a)

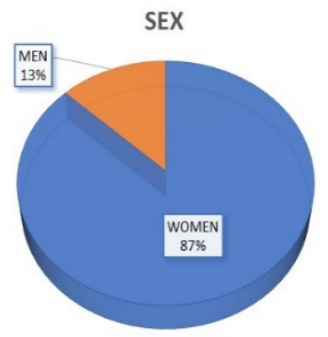

(b)

Fig. 2. Proportion Age and Sex

(a) Age, (b) Sex

According to data from Fisheries Integrated Service Unit 2019, the population density in Muara Angke reaches 474,03 people per square kilometre (very densely populated). The house and neighborhood condition is very tight (Figure 3 ).

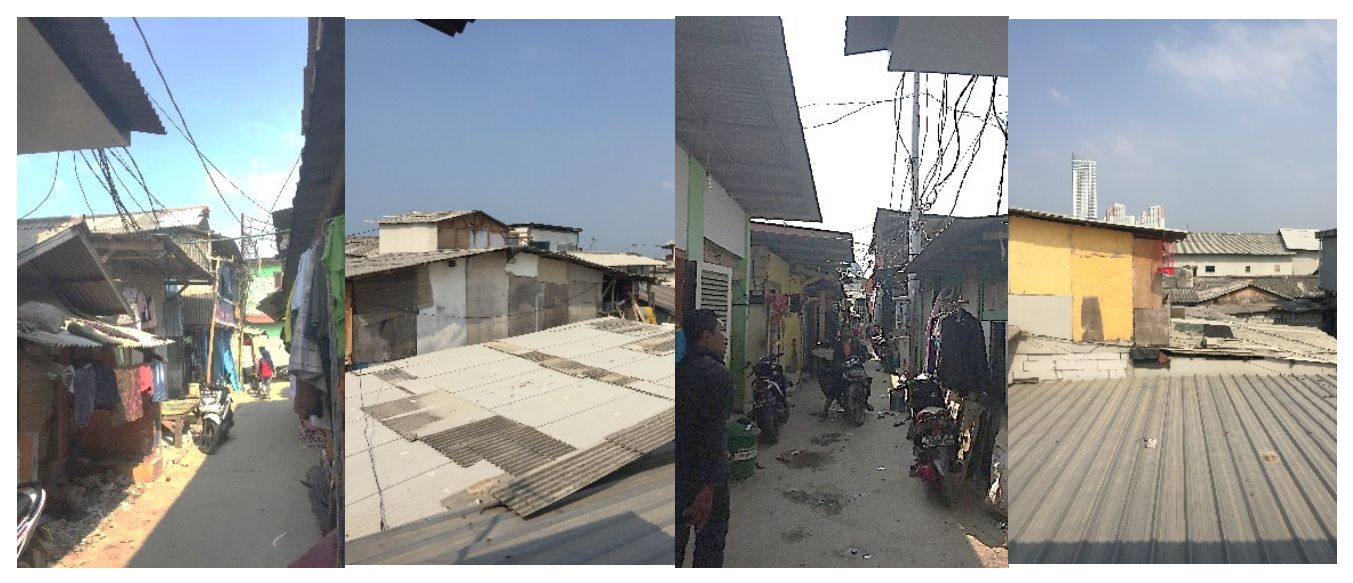

Fig. 3. The House Conditions 
It was observed from the field survey that about $57 \%$ of people can only complete education up to elementary school, $29 \%$ of respondent can complete up to junior high school, and only $1 \%$ of respondent can complete up to diploma (Figure 4.a). This data shows that the majority of the respondent in Muara Angke has a final education in elementary school. The distribution of occupation of the household is presented in Figure 4.b. The occupation of the majority of the respondent is housewife (74\%).

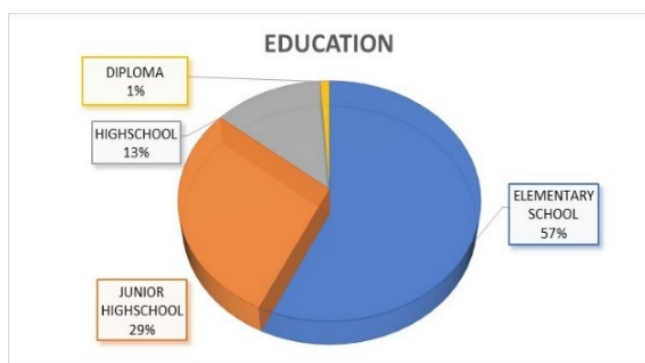

(a)

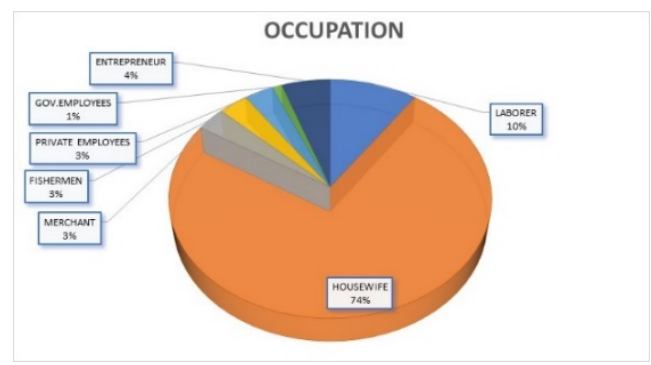

(b)

Fig. 4. Proportion of Education and Occupation

(a) Education, (b) Occupation

It has been found from the survey that most of the respondents (43\%) earned between IDR 1.100.000 to IDR 2.000.000 per month and 24\% respondents earned between IDR 2.100.000 to IDR 3.000.000 per month (Figure 5.a). Income groups of IDR 3.100.000 - IDR 4.000.000 (8\%) and IDR 4.100.000 - IDR 6.000.000 (1\%) represent the lowest percentage of income level groups. Figure 5.b shows that most of the respondents' annual expenditure to buy water is around IDR 200.000 - IDR 500.000 (70\%) every month.

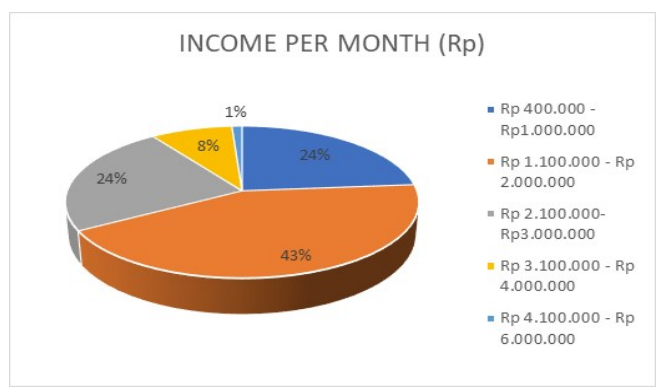

(a)

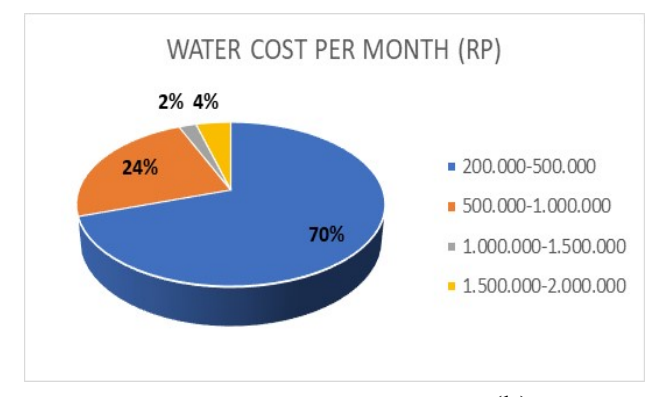

(b)

Fig. 5. Proportion of income and Water Cost

(a) Income, (b) Water Cost

Overall, the average expenditure to buy water in a month is IDR 482,183 or $23 \%$ of the respondents' average income (IDR 2,056,989). This shows that the population does not have good access to clean water. Good access to clean water can be realized if at least the expenditure of water can be reached less than $10 \%$ of total household income [9]. Most people in the study area pay well water to the owners, buy a tank and or gallon water from a local vendor to fulfill their water needs (Figure 6). 


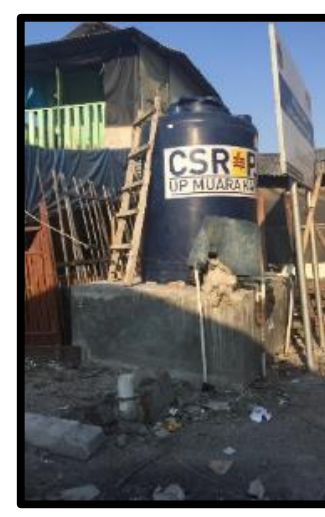

(a)

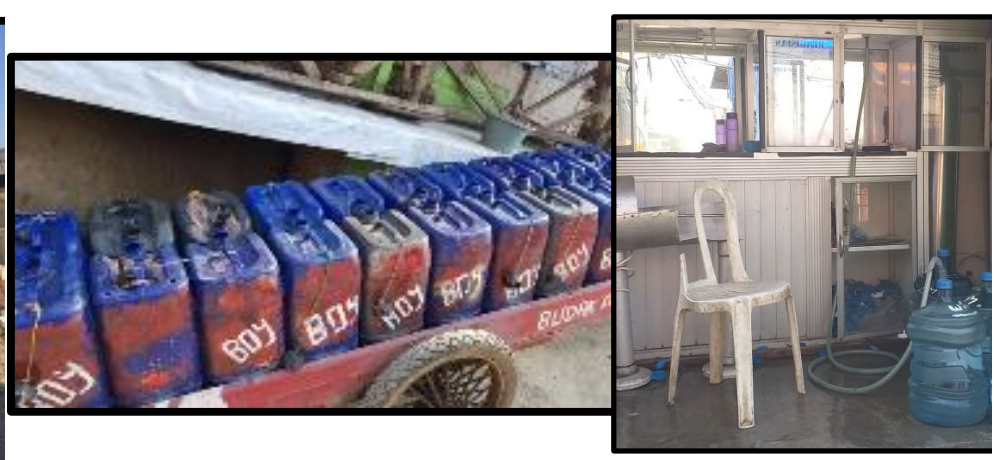

(b) (c)

Fig. 6. Water Source

(a) Deepwell Reservoir; (b) Tank Water; (c) Gallon Water

\subsection{Acceptance of Rainwater Harvesting (RWH)}

Based on the result of initial survey (July 12, 2019) and the distribution of questionnaires to 19 residents, 15 residents of Muara Angke claimed to have known about RWH, while four residents did not know anything about RWH. However, residents who already know about rainwater harvesting did not have the willingness to adopt and use it. Due to economic reason (expensive initial investment) and due to perception of the quality of rainwater that is not good when it's compared with the other water sources.

The result from Forum Group Discussion (FGD) (July 26, 2019) and Socialization (August 30, 2019) were representative of Muara Angke residents, majority of residents and the local government strongly supporting the adoption of RWH in Muara Angke area (Figure 7). Rainwater Harvesting can be an alternative of water source for residents.

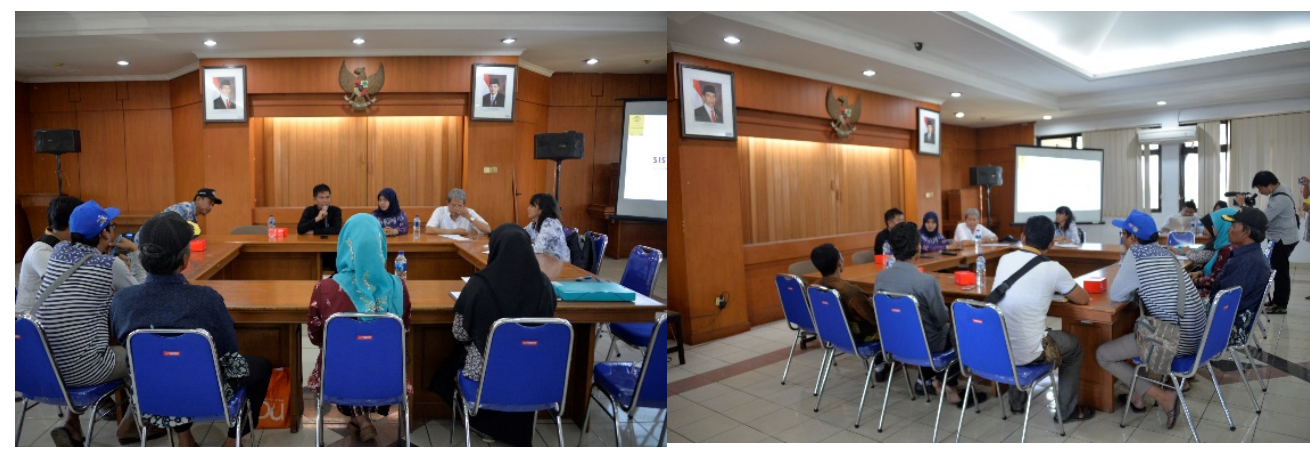

(a) 

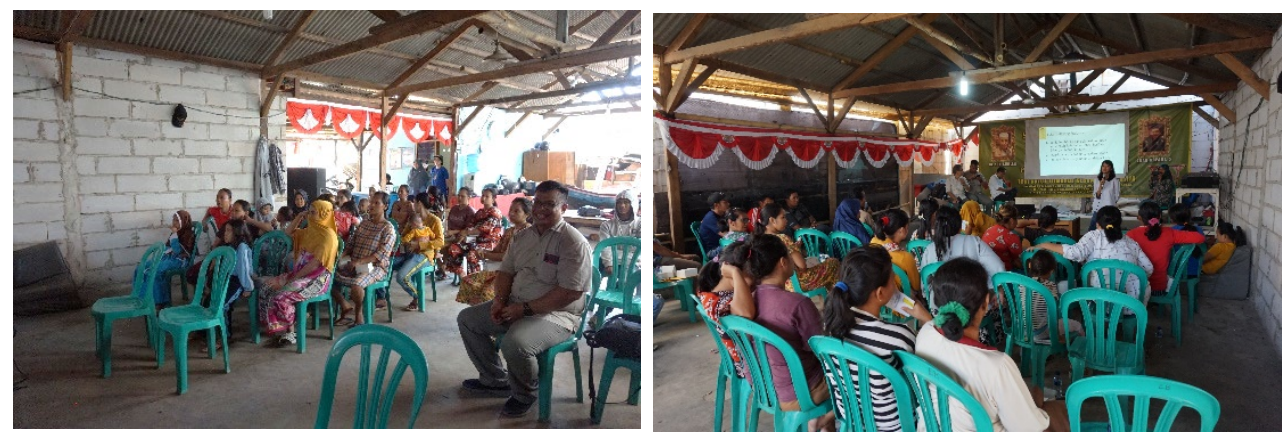

(b)

Fig. 7. FGD and Socialization Program

(a) FGD; (b) Socialization

Rainwater Harvesting is the technique through which rainwater is captured from roof catchment and stored in tanks/reservoirs/groundwater aquifers [10]. According to Worm dan Hattum [11], there are three basic components in rainwater harvesting: catchment/rainwater collection facilities (roof); delivery system, and storage (Figure 8). The obstacle to adoption RWH in this area are residents need to prepare a substantial initial investment fund and residents need to provide land for water storage tanks in their area.

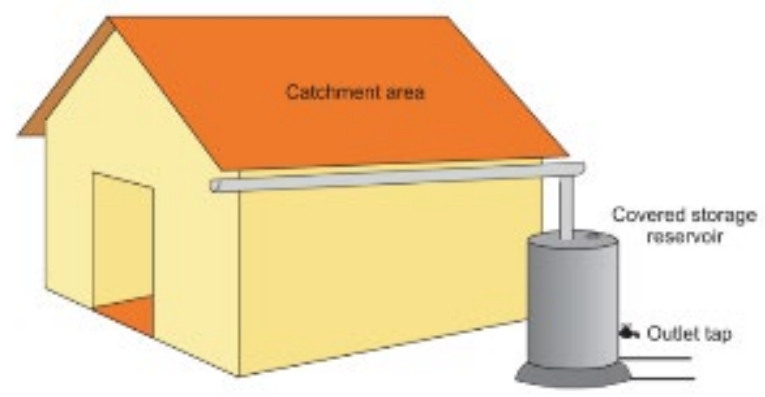

Fig. 8. Rainwater Harvesting System Scheme

Based on the results of processing MDS analysis, stimulus coordinates are obtained from each indicator shown in Table 1. 
Table 1. Stimulus Coordinates on each indicator

\begin{tabular}{clcc}
\hline $\begin{array}{c}\text { Stimulus } \\
\text { Number }\end{array}$ & \multicolumn{1}{c}{ Stimulus Name } & \multicolumn{2}{c}{ Dimension } \\
\hline 1 & Participation & 0.8024 & -0.7641 \\
2 & Social Capital & 0.7813 & 0.4233 \\
3 & Government Support & 1.6292 & 0.0292 \\
4 & Quality of Rainwater & 0.3526 & -1.0508 \\
5 & Quantity of Rainwater & -2.2704 & -0.4593 \\
6 & Continuity of Rainwater & 0.7395 & 0.4907 \\
7 & Ability to Pay & -1.7725 & 1.1029 \\
8 & Maintenance Costs & -0.9998 & 0.0202 \\
9 & Saving & 0.7377 & 0.2078 \\
\hline
\end{tabular}

Based on the coordinates of the table above, a position map of each indicator can be generated with the configuration shown in Figure 9.

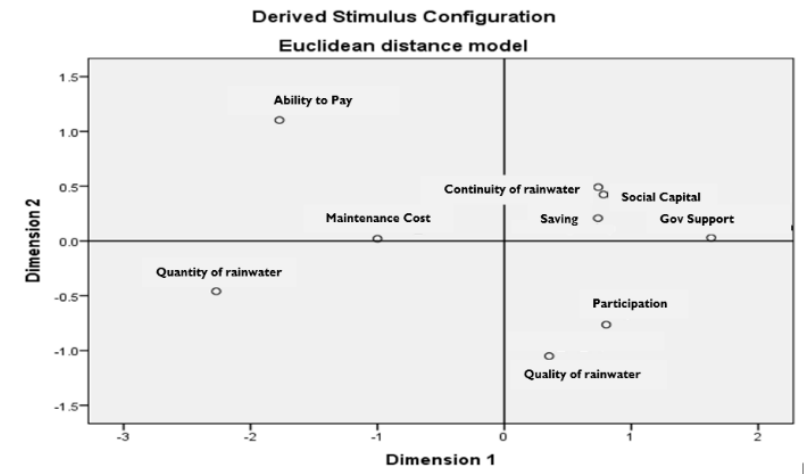

Fig. 9. Perceptual Map each Indicator

It can be seen that perception of people acceptance on continuity of rainwater, social capital, saving, and government support has similarities because located close together and in the same quadrant I. Perception of people acceptance on participation and quality of rainwater also have similarities because located close together and in the same quadrant IV. While the ability to pay, maintenance cost, and quantity of rainwater were located far apart from one another, in other words, the perception of people acceptance of these three indicators is different and dissimilar with other indicators.

In order to see the perception of people acceptance of RWH after socialization, questionnaires were distributed, and 93 respondents had answered the questionnaires. The average scoring results are shown in Figure 10. 


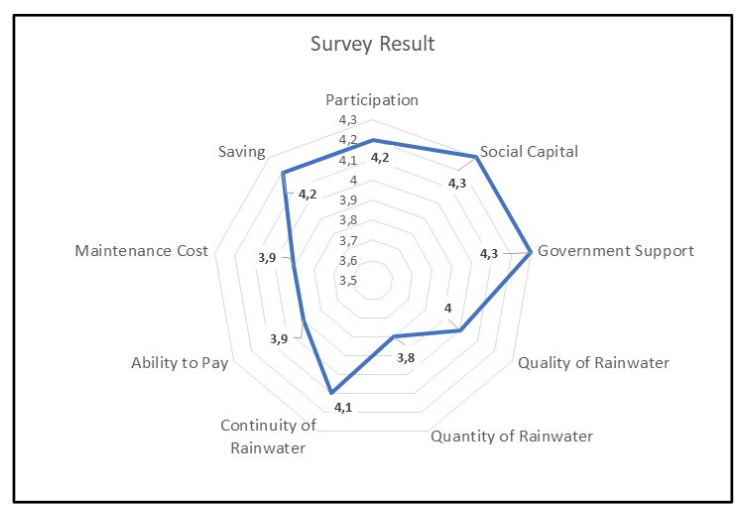

Fig. 10. Survey Result

In the Social Aspect, Indicators of participation (average score: 4.2), social capital (4.3) and government support (average score; 4.3) have almost the same average value (above 4.0). From the environmental aspect, continuity of rainwater has the highest average score (4.1), the followed by quality of rainwater (average score: 3.8 ) and quantity of rainwater (average score: 3.8). The economic aspect shows that only the saving indicator has an average score above 4.0. Indicators of Maintenance cost (average score: 3.9 ) and ability to pay (average score: 3.9 ).

Table 2. Perception Level Range

\begin{tabular}{cc}
\hline Perception & Range Average Score \\
\hline Very good & $4.2-5.0$ \\
good & $3.4-4.2$ \\
Average & $2.6-3.4$ \\
Fair & $1.8-2.6$ \\
Poor & $1.0-1.8$ \\
\hline
\end{tabular}

Based on the average value of scoring results, 7 from 9 indicators (participation, quality of rainwater, quantity of rainwater, continuity of rainwater, ability to pay, maintenance cost, and saving) belong to the level "good" perception and 2 other indicators (social capital and government support) belong to the level "very good" perception (Table 2.). However, some respondents have "average" level of perception on the indicators: quantity of rainwater (30\%), ability to pay $(26 \%)$, and maintenance costs $(23 \%)$.

\subsection{Discussion}

The impacts of the phenomenon of climate change greatly affect people's livelihoods as a fisherman in the coastal area [12]. The water demand in the coastal settlement will higher every time. This is because population growth is rise rapidly every year, so the need for settlement is intensifying [12]. The coastal area has its carrying capacity, including for water supply resources. Prevention of physical, ecological, economic, and socio-cultural degradation in coastal areas requires the concept of coastal carrying capacity, so that later it can determine how 
well the quality of coastal area users is based on natural, cultural, and location resources [13] Successful implementation of rainwater harvesting requires cooperation from all parties in society. Research conducted by Karim [14] In Bangladesh, revealed that community perception of RWH was perfect as the primary source of drinking and cooking. The community stated that the rainwater in their area has satisfactory water quality. According to Asmuni [15], the community already has good knowledge and perceptions on RWH. However, the main reason underlying them to implement RWH is if it can reduce their household water bills. Barthwal [16] found that most respondents in Dehradun, India, were aware of the importance of adopting the RWH for their households. However, income, awareness, government policies, and incentives are the determining factors for RWH implementation at the household level.

\section{Conclusion}

The people acceptance of rainwater harvesting systems in fisheries settlement coastal area Muara Angke, North Jakarta was assessed through a questionnaire survey. It reveals from the study that there was a change in people perception before and after socialization. The people perception toward RWH became better after socialization, especially on indicators of ability to pay and quality of rainwater. However, it should be noted that there are respondents who have "average" perception of three indicators: ability to pay $(26 \%)$, maintenance cost $(23 \%)$, and quantity of rainwater $(30 \%)$.

Acknowledgements. This work was financially supported by the Universitas Indonesia through Community Dedication (International Indexed Publication for Master Students NKB1442/UN2.R3.1/HKP.05.00/2019) funding program in 2019 fiscal year.

\section{References}

[1] S. Basack, P. Maity, A. Bhattacharya, A, "A Coastal Groundwater Management Model with Indian Case Study,” Water Management Vol. 167, Issue WM3, 2014.

[2] WaterAid, "Handbook on climate change and disaster resilient water, sanitation and hygiene practices,". Dhaka, Bangladesh: Wateraid in Bangladesh, 2012.

[3] M.A. Abedin, U. Habiba, and R. Shaw, "Community perception and adaptation to safe water scarcity: Salinity, arsenic and drought risks in coastal Bangladesh,” International Journal of Disaster Risk Science, 5(2): 110-124, 2014.

[4] A. Akter, and S. Ahmed,"Potentiality of rainwater harvesting for an urban community in Bangladesh,"Journal of Hydrology, 528 84-93, 2015.

[5] A. Campisano, G. D'amico, C. Modica, "Water Saving and Cost Analysis of Large-Scale Implementation of Domestic Rain Water Harvesting in Minor Mediterranean Islands," Water, 9, 916, 2017.

[6] S.P. Sari, and Suhendri, "Potential of Rainwater System for Domestic Building in Jakarta," IOP Conf, Series: Earth and Environmental Science 151 012002, 2018.

[7] H. Furumai, "Evaluation of rainwater harvesting and use potential considering climate change in Arakawa watershed," The University of Tokyo: Research Centre for Water Environment Technology, 2016.

[8] M.J. Shalamzari, B.V. Sheikh, A. Saddodin, A.A. Sarvestani, "Public Perception and Acceptability toward Domestic Rainwater Harvesting in Golestan, Limits to Up-Scaling," Ecopersia, 4(3): 1437-1454, 2016. 
[9] B.C. Arimah, "Slums as Expressions of Social Exclusion: Explaining The Prevalence of Slums in African Countries," United Nations Human Settlements Programme (UNHABITAT) Nairobi, Kenya, 2010.

[10] P.S. Mathur, D. Prasad, D.K. Sharma, "Rainwater Harvesting and Utilisation, Blue Drop Series," Book 2: Beneficiaries \& Capacity Builders, United Nations Human Settlements Programme (UN-HABITAT), Water, Sanitation and Infrastructure Brach, Nairobi, Kenya, 2005.

[11] J. Worm, and T. Hattum, "Rainwater harvesting for domestic use," Agrodok 43, Wageningen: Agromisa Foundation and CTA, 2006.

[12] A.P. Zulriskan, H.S. Hasibuan, R.H. Koestor, "Spatial Planning of Small Island to Anticipating Climate Change Effect (Case Study of Harapan and Kelapa Islands, Indonesia), " International Conference on Climate Change, IOP Conf. Series: Earth and Environmental Science 200 012064, 2018.

[13] A.F. Alwini, H.S. Hasibuan, R.H. Koestoer, "Spatial Planning Based on Carrying Capacity: Study of Sustainable Coastal Area Management," ICENIS, 2018.

[14] M.R. Karim, A.B. Shelly, M. Bisws, "People Perception and Acceptance of Rainwater Harvesting in a Coastal Area in Bangladesh,”. Khulna University of Engineering \& Technology, Bangladesh, 2004.

[15] S. Asmuni, R. Baah, S. Yusoff, F.N. Ridzuan, F.N. "Public Acceptance and Preference Towards Rainwater Harvesting in Klang Valley, Malaysia," Journal of Emerging Economies and Islamic Research, 2016.

[16] S. Barthwal, S.C. Barthwal, H. Goyal, B. Nirmani, B. Awasthi, "Socio-economic acceptance of Rooftop Rainwater Harvesting," Urban Water Journal, Vol.11, No.3,231$239,2014$. 